\title{
PENTINGNYA PENDIDIKAN BAGI MANUSIA
}

\author{
Oleh. \\ Yayan Alpian, M.Pd., Sri Wulan Anggraeni, M.Pd., \\ Unika Wiharti., Nizmah Maratos Soleha. \\ Yayan.alpian@ubpkarawang.ac.id \\ Wulan.anggraeni@ubpkarawang.ac.id \\ unikawiharti06@gmail.com \\ Nizmahms@gmail.com \\ PGSD Fakultas Keguruan dan Ilmu Pendidikan \\ Universitas Buana Perjuangan Karawang
}

\begin{abstract}
ABSTRAK
Tujuan kegiatan Pengabdian kepada Masyarakat ini adalah bertujuan untuk mensosialisasikan, memberikan pengetahuan dan pemahaman mengenai pentingnya pendidikan bagi manusia serta memberikan motivasi kepada warga masyarakat di Desa Mulyasejati Kecamatan Ciampel Kabupaten Karawang. Pengabdian Pada Masyarakat ini merupakan wahana bagi Program Studi PGSD untuk mengabdikan keilmuannya.

Khalayak sasaran Pengabdian kepada Masyarakat ini adalah Para warga sekitar Desa Mulyasejati Kecamatan Ciampel Kabupaten Karawang yang merupakan warga yang bermatapencaharian sebagai petani, buruh, dan juga ibu rumah tangga dan anak-anak usia Sekolah Dasar yang berjumlah 45 orang dari yang direncanakan 80 orang. Metode kegiatan ini adalah penyuluhan dan sosialisasi yang dikemas dalam bentuk workshop selama 1 hari mengenai penyampaian materi hakikat manusia, hakekat manusia dan kebutuhan akan pendidikan, pengertian pendidikan.

Pelaksanaan kegiatan Pengabdian kepada Masyarakat berupa workshop ini didukung oleh beberapa faktor yang memberikan banyak kontribusi atas keberhasilan kegiatan Pengabdian kepada Masyarakat. Pelaksanaan dilakukan dengan workshop, menggunakan metode ceramah yaitu dengan teknik presentasi, dilanjutkan dengan diskusi tanya jawab sebagai bentuk kegiatan workshop. Hasil pelaksanaan Pengabdian kepada Masyarakat menunjukkan tingkat pemahaman peserta pengabdian kepada masyarakat mengenai pentingnya pendidikan, peserta lebih tersadarkan akan pentingnya pendidikan dan memiliki motivasi tinggi untuk terus melanjutkan pendidikan ke jenjang yang lebih tinggi.
\end{abstract}

\section{Kata Kunci: Pendidiakn, Manusia}




\section{A. PENDAHULUAN}

Pendidikan merupakan hal yang terpenting dalam kehidupan manusia, ini berarti bahwa setiap manusia Indonesia berhak mendapatkannya dan diharapkan untuk selalu berkembang didalamnya, Pendidikan tidak akan ada habisnya, Pendidikan secara umum mempunyai arti suatu proses kehidupan dalam mengembangkan diri tiap individu untuk dapat hidup dan melangsungkan kehidupan. Sehingga menjadi seorang yang terdidik itu sangat penting. Manusia dididik menjadi orang yang berguna baik bagi Negara,Nusa dan Bangsa. Lingkungan pendidikan pertama kali yang diperoleh setiap insan yaitu di lingkungan keluarga (Pendidikan Informal), lingkungan sekolah (Pendidikan Formal), dan lingkungan masyarakat (Pendidikan Nonformal). Pendidikan Informal adalah pendidikan yang diperoleh seseorang dari pengalaman sehari-hari dengan sadar atau tidak sadar, sejak seseorang lahir sampai mati. Proses pendidikan ini berlangsung seumur hidup. Sehingga peranan keluarga itu sangat penting bagi anak terutama orang tua. Orang tua mendidik anaknya dengan penuh kasih sayang. Kasih sayang yang diberikan orang tua tidak ada habisnya dan terhitung nilainya. Orang tua mengajarkan kepada kita hal-hal yang baik misalnya, bagaimana kita bersikap sopan-santun terhadap orang lain, menghormati sesama, dan berbagi dengan mereka yang kekurangan.

Sekolah sebagai lembaga formal yang diserahi tugas untuk mendidik. Peranan Sekolah sangat besar sebagai sarana tukar pikiran diantara peserta didik. Dan juga, Guru harus berupaya agar pelajaran yang diberikan selalu cukup untuk menarik minat anak, sebab tidak jarang anak menganggap pelajaran yang diberikan oleh Guru kepadanya tidak bermanfaat. Tugas Guru yang hanya semata-mata mengajar saat ini sudah keluar dari aturan-aturan itu .Guru harus mendidik yaitu harus membina para anak didik menjadi manusia dewasa yang bertangging jawab. Hanya dengan inilah maka semua aspek kepribadian anak bisa berkembang.

Peranan pendidikan sangat besar dalam mempersiapkan dan mengembangkan Sumber Daya Manusia (SDM) yang handal yang mampu bersaing secara sehat tetapi juga memiliki rasa kebersamaan dengan sesama manusia meningkat. Ilmu pendidikan termasuk salah satu cabang ilmu pengetahuan yang 
sifatnya praktis karena ilmu tersebut ditujukan kepada paraktek dan perbuatanperbuatan yang mempengaruhi anak didik. Mendidik bukanlah Perbuatan sembarangan karena menyangkut kehidupan dan nasib anak manusia untuk kehidupan selanjutnya, yaitu manusia sebagai makhluk yang bermartabat dengan hak-hak asasinya. Itulah sebabnya melaksanakan pendidikan merupakan tugas moral yang tidak ringan.

Sedemikkiian pentingnya pendidikan dalam upaya mencerdaskan kehidupan bangsa, meningaktakan kesejahteraan masyarakat, dan membangun dan membangun martabat bangsa, maka pemerintah berusaha memberikan perhatian yang sungguh-sungguh untuk mengatasi berbagai masalah di bidang peningkatan pendidikan mulai dari tingkat dasar, menengah, sampai tingkat tinggi. Perhatian tersebut antara lain ditujukan dengan cara menyediakan alokasi anggran yang berarti. Serta membuat kebijakan-kebijakan yang berkaitan dengan usaha meningkatkan mutu pendidikan. Bahkan yang lebih penting lagi adalah terus melakukan berbagai macam ikhtiar guna memperluas kesempatan bagi masyarakat dalam memperoleh penmdidikan pada semua jenjang yang ada.

Hal ini diperkuat oleh pengertian pendidikan yang di tertuang dalam UU SISDIKNAS No.20 tahun 2003 bahwa pendidikan adalah usaha sadar terencana untuk mewujudkan suasana belajar dan proses pembelajaran agar peserta didik secara aktif mengembangkan potensi dirinya untuk memiliki kekuatan spiritual keagamaan, pengendalian diri, kepribadian, kecerdasan, akhlak mulia, serta ketrampilan yang diperlukan dirinya, masyarakat, bangsa dan negara. Dalam pengertian yang sederhana dan umum makna pendidikan sebagai usaha manusia untuk menumbuhkan dan mengembangkan potensi-potensi pembawaan baik jasmani maupun rohani sesuai dengan nilai-nilai dan norma-norma yang ada dalam masyarakat.

Selain untuk menumbuhkan dan mengembangkan potensi dalam diri manusia, pendidikan juga penting bagi kehidupan itu sendiri yaitu diantaranya bahwa pendidikan untuk dapat meningkatkan karir dan pekerjaan, dimana dengan pendidikan manusia dapat mendapatkan keahlian yang diperlukan dalam dunia kerja serta membantu dalam mewujudkan perkembangan karir. Keahlian 
merupakan pengetahuan yang mendalam mengenai suatu bidang tertentu yang dapat membuka peluang karir bagus untuk masa depan. Sehingga dengan adanya pendidikan yang layak dan baik maka dapat membantu kita sebagai manusia untuk mewujudkan impian.

Tidak hanya sebatas untuk pengembangan potensi dan meningkatkan karir dalam mendapatkan pekerjaan bahwa pendidikan sangat penting untuk menjadikan manusia agar lebih baik karena membuat kita beradab. Pada umumnya Pendidikan adalah dasar dari budaya dan peradaban. Pendidikan membuat kita sebagai manusia untuk berpikir, menganalisa, serta memutuskan. Menumbuhkan karakter pada diri sendiri juga merupakan tujuan dengan adanya pendidikan, sehingga menciptakan Sumber Daya Manusia yang lebih baik.

Sebuah efek langsung dari pendidikan adalah dengan adanya mendapatkan pengetahuan yang luas. Pendidikan memberikan pelajaran yang begitu penting bagi manusia mengenai dunia sekitar, mengembangkan perspektif dalam memandang kehidupan. Pendidikan yang sebenarnya diperoleh dari pelajaran yang diajarkan oleh kehidupan kita. Maka dari itu banyak pemerintah yang menganjurkan pendidikan yang baik di mulai sejak dini, agar ketika kelak dewasa mempunyai Sumber Daya Manusia yang baik. Dengan adanya pendidikan dapat menghapuskan keyakinan yang salah di dalam pikiran kita. Selain itu juga dapat membantu dalam menciptakan suatu gambaran yang jelas mengenai hal di sekitar kita, juga dapat menghapus semua kebingungan. Orang dengan pendidikan yang tinggi biasanya akan lebih bijak dalam menyelesaikan suatu masalah, hal ini dikarenakan mereka sudah mempelajari mengenai ilmu pendidikan dalam kehidupan.

Mengacu pada permasalahan yang diajukan untuk dipecahkan, maka tujuan kegiatan ini adalah:

1. Memberikan penyuluhan dan sosialisasi pentingnya pendidikan bagi manusia yang diberikan kepada warga masyarakat Desa Mulyasejati Kecamatan Ciampel Kabupaten Karawang.

2. Memberikan pemahaman mengenai pentingnya pendidikan bagi manusia yang diberikan kepada warga masyarakat Desa Mulyasejati Kecamatan Ciampel Kabupaten Karawang.. 


\section{B. METODE}

Permasalahan yang ada di warga masyarakat Desa Mulyasejati Kecamatan Ciampel Kabupaten Karawang masih kurang memahami pentingnya pendidikan diselesaikan menggunakan metode ceramah dengan teknik presentasi materi pengetahuan tentang pentingnya pendidikan bagi manusia dilanjutkan dengan diskusi. Kegiatan ini dikemas dalam bentuk workshop.

\section{Langkah-langkah kegiatan}

Berikut ini adalah langkah-langkah pelatihan yang dilakukan:

1. Tahap Persiapan

Tahap persiapan yang dilakukan meliputi:

a) Survey

Sebelum melaksanakan kegiatan pengabdian masyarakat terlebih dahulu dilakukan survey lokasi kegiatan yang berada di Desa Mulyasejati Kecamatan Ciampel Kabupaten Karawang. Survey dimaksudkan untuk melihat situasi kebutuhan terkait pengabdian masyarakat dan sejauh mana tingkat kebutuhan yang diperlukan oleh peserta kegiatan pengabdian masyarakat tersebut.

b) Pemantapan dan penetuan lokasi dan sasaran

Penyusunan bahan/materi penyuluhan dan sosialisasi, yang meliputi: materi dengan media power point bagi warga masyarakat Desa Mulyasejati Kecamatan Ciampel Kabupaten Karawang.

2. Tahap Pelaksanaan Kegiatan

Tahap pelaksanaan kegiatan dilakukan persiapan. Dalam tahap ini dilakukan pertama, penjelasan materi terkait tentang pentingnya pendidikan bagi manusia, sesi penyuluhan dan sosialisasi ini menitikberatkan pada pemberian pengetahuan, penjelasan serta memotivasi para warga masyarakat agar mau meningkatkan dan meneruskan pendidikan ke jenjang lebih tinggi.

3. Metode Pelatihan

Untuk melaksanakan kegiatan tersebut digunakan beberapa metode pelatihan, yaitu: 


\section{a. Metode Ceramah}

Metode ceramah dipilih untuk memberikan pengetahuan dan penjelasan tentang materi pentingnya pendidikan bagi manusia: memberikan pemahaman kepada warga masyarakat mengenai hakikat manusia, hakekat manusia dan kebutuhan akan pendidikan, pengertian pendidikan.

b. Metode Tanya Jawab

Metode tanya jawab sangat penting bagi para peserta kegiatan, baik di saat menerima pengetahuan dan penjelasan materi mengenai hakikat manusia, hakekat manusia dan kebutuhan akan pendidikan, pengertian pendidikan. Metode ini memungkinkan warga masyarakat menggali pengetahuan sebanyak-banyaknya tentang pentingnya pendidikan bagi manusia.

\section{HASIL DAN PEMBAHASAN}

Kegiatan penyuluhan dan sosialisasi diharapkan dapat memotivasi dan menumbuhkan kesadaran bagi warga masyarakat Desa Mulyasejati Kecamatan Ciampel Kabuoaten Karawang akan tentang pentingnya pendidikan bagi manusia. Kegiatan ini berjalan dengan baik dan lancar serta diikuti oleh warga sekitar dengan antusias, terbukti dengan banyaknya warga yang hadir ke tempat penyelenggaraan kegiatan tersebut. Mereka mengikuti kegiatan hingga akhir kegiatan berlangsung.

Materi mengenai hakikat manusia, hakekat manusia dan kebutuhan akan pendidikan, pengertian pendidikan, penting untuk disampaikan karena sebagai pengembangan kompetensi dirinya dalam mengarungi kehidupan yang ada pada zaman modern sekarang ini. Sebab jika kita tidak memiliki ilmu pengetahuan dan bahkan tidak mengikuti pendidikan dalam kehidupan, maka kita akan tergerus oleh perkembangan zaman yang semakin maju. Oleh karena itu, pentingnya pendidikan bagi manusia untuk menghadapi tantangan zaman sekarang ini. Dengan pendidikan diharapkan manusia dapat mengembangkan kompetensi dirinya seperti mudah mendapatkan pekerjaan, mengembangkan karir dalam dunia kerja, menambah pengetahuan, menjadi manusia yang beradab, memiliki pola pikir yang maju, sehingga memiliki pengetahuan yang luas dan dapat menyelesaikan berbagai macam permasalahan dengan tepat dan benar. 
Hasil pelaksanaan Pengabdian Pada Masyarakat menunjukkan masih kurangnya keberhasilan karena peserta yang hadir hanya sebanyak 45 orang warga masyarakat dari rencana 80 orang. Meskipun demikian, kegiatan Pengabdian Pada Masyarakat yang tujuan utamanya adalah memberikan pemahaman, pengetahuan, dan penjelasan tentang pentingnya pendidikan bagi manusia. Hal ini dapat dilihat dari antusiasnya para warga masyarakat dalam mengikuti seluruh kegiatan pelatihan, baik dalam pemberian materi. Para warga masyarakat juga memperlihatkan antusiasnya ketika melakukan diskusi.

\section{KESIMPULAN DAN SARAN}

Berdasarkan hasil pelaksanaan kegiatan Pengabdian Pada Masyarakat, maka dapat disimpulkan bahwa kegiatan Pengabdian Pada Masyarakat "Penyuluhan dan Sosialisasi Pentingnya Pendidikan bagi Manusia di Desa Mulyasejati Kecamatan Ciampel Kabupaten Karawang" yaitu warga masyarakat lebih termotivasi untuk meningkatkan taraf hidupnya dengan terus melanjutkan pendidikan ke jenjang yang lebih tinggi. Karena hal ini, pendidikan sangatlah penting bagi manusia, dengan pendidikan kita bisa mengembangkan kompetesi diri untuk menjawab tantangan perkembangan zaman yang semakin maju dan modern. Dengan pendidikan bisa menjadi manusia yang seutuhnya, karena sebagai manusia kita harus memiliki pengetahuan, sikap, serta adab yang luhur sebagai implementasi dari pendidikan itu sendiri.

\section{DAFTAR PUSTAKA}

Aqiyuddin, M., (2005). Pendidikan Untuk semua (Dasar dan Falsafah Pendidikan Luar Sekolah). Cirebon: STAIN Cirebon Press.

Munib, A. dkk. 2012. Pengantar Ilmu Pendidikan. Semarang: Pusat Pengembangan MKU/MKDK-LP3 Universitas Negeri Semarang.

Purwanto, N. 2007 Ilmu Pendidikan Toerirtis dan Praktis. PT Remaja Rosdakarya Bandung

Shene. H.G. 1984. Arti Pendidikan Bagi Masa Depan. Jakarta: Pustekum, Dikbud: CV Rajawali

Tirta R. U, Lasulo, SL. 2005 Pengantar Pendidikan Rineka Cipta Jakarta. 